\title{
Could Health Court Be a Solution?
}

\author{
Solmaz Khodapanahandeh ${ }^{1} \&$ Siti Naaishah Hambali $^{1}$ \\ ${ }^{1}$ Faculty of Law, Universiti Kebangsaan Malaysia, Bangi, Selangor, Malaysia \\ Correspondence: Solmaz Khodapanahandeh, Faculty of Law, Universiti Kebangsaan Malaysia, 43600 Bangi, \\ Selangor, Malaysia. Tel: 60-10-896-4827. E-mail: Solmaz_kh2003@yahoo.com
}

Received: June 14, 2013 Accepted: August 29, 2013 Online Published: October 29, 2013

doi:10.5539/ass.v9n15p138

URL: http://dx.doi.org/ass.v9n15p138

\begin{abstract}
Tort compensation system has been known as inefficient system for delivering compensation as well as non-legal remedy such as explanation and apology. Essentially, the system is costly and lengthy as there is considerable delay between the accident and its compensation, and also it is inequitable and unfair between injured patients. There are some serious obstacles to sue doctors because of the difficulty in obtaining expert evidence. Thus, only few injured patients get compensation. This paper aims to examine the health court as a substitute for the present tort litigation system and explore its merits for solving medical negligence claims. The employed methodology for doing this research is a library one. The data collected both electronically (PubMed, Medline \& Google Scholar) and manually (based on different papers, journals, books \& researches) and the key words and phrases such as "Medical Negligence", "Tort system" and "Health Court" were used to obtain public policy studies, case analyses, law review articles and healthcare analysis articles.
\end{abstract}

Keywords: medical negligence, tort system, health court, compensation

\section{Introduction}

The present tort litigation system has not provided many victims of medical injuries with fair and adequate compensation. The system is slow, inefficient and unrealistically difficult for many medical injured victims (McLean, 1988). Rehabilitation is also hindered by the prolonged adversarial system (Kassim, 2003). This is very hard for the plaintiff to succeed in medical negligence action, while there are fundamentally logistical difficulties of continuing an action (Davies, 1998). Thus, inaccessibility of the litigation system and particular difficulties of proving medical malpractice discourage many potential litigants from pursuing their claim. This means that those cases that are pursued are unrepresented of the number of medical errors that have occurred. According to the study performed by Localio, Lawthers and Brennan (1991) and Studdert, Mello and Gawande (2006), it is believed that in the best situation negligence file claims resulted in merely 2 to 3 percent of injuries, merely $50 \%$ of applicants recover money, and litigation is set incongruously with the value of the claim (that is in meritorious cases, no money is given) around a quarter of the period.

Due to these difficulties, alternatives to tort system have been proposed in many countries in different ways. Some countries such as New Zealand, Finland, Denmark and Sweden abolished tort system totally and created new system in favor of using No-Fault compensation system (Danzon, 1994). Some others have enacted reforms in their system in order to figure out or at least improve tort issues (Hitzhusen, 2005) and several countries have adopted alternative dispute resolution methods (Sohn \& Bal, 2012). The present paper aims to examine the health court as a substitute to the present tort litigation system that was primarily suggested by the Harvard School of Public Health.

\section{Tort System Issues}

Compensation is allocated under the current tort litigation system when it is proved that the negligence of care is the injury cause. In a lawsuit based on medical negligence, a plaintiff must prove the specific standard of care owed by the defendant doctor (duty), the defendant's breach of the applicable standard of care (breach), and that the defendant's breach caused the damages claimed by the plaintiff (causation \& damages). If each of these elements is proven, the plaintiff may recover money damages for those items losing wages, medical expenses and suffering under tort law.

It is not easy to define the standard of care, by jury especially in cases of medical negligence that were known as the most complicated claims whether it was violated by the physician or the injury was actually resulted from the 
violation. Furthermore, due to its adversarial nature, the tort system necessitates that the contesting parties define the theme of the dispute between them and provide the evidence to the court for decision making. The court's task is to judge according to the law and the existing evidence. Yet according to Tay, See \& Tan (1998), occasionally the litigation cannot attain actual justice between the opposing parties due to intrinsic flaws in the adversarial system.

Consequently, juries might come to decisions more on whether they liked or detested the plaintiff, the physician, or the relevant professional witnesses instead of whether negligence really happened. Indeed, little connection exists between true negligence and verdicts. Only $15 \%$ of all medical liability trials are actually based on the true negligence (Chen \& Sohn, 2012). One of the main problems with the current tort system is that juries make particularized decisions about the standard of care, leading to inconsistent application from jury to jury (Chow, 2007)

\section{Health Court}

The Harvard School of Public Health first proposed health courts that moved cases of medical liability from jury trials to specific courts with judges skilled in medical issues. Some details of health court proposals are different. As Mello et al. (2006) mentioned, certain proposals suggest that a single court administers all providers and patients in a single clinical or geographic area, whereas the Common Good/Harvard/ proposal implies that court administers a certain group of insurers. Some favor health experts over judges (Mello \& Gallagher, 2010). Moreover, some claim that a plaintiff who is not content with her/his award should merely plea to an administrative judge inside the health court system, whereas others advocate appeals done via regular claims of medical malpractice.

Chow (2007) has stated undoubted preference for edictal courts. The most developed and well-known plan for health courts is Common Good's model, which replaces juries with a tribunal of judges with medical expertise gained through education or experience to establish a uniform standard of care (Romano, 2003). Special court for medical negligence claims or health court has two important characteristics: (i) existence of expert judges who have relevant background or gain expertise through handling medical negligence cases exclusively instead of jury and (ii) impartial experts in the relevant area of medicine.

\section{Expert Judges}

In order to develop a uniform standard of care for physicians, the health court model stops the use of juries in medical negligence cases and instead calls full time judges for review who are devoted exclusively to healthcare cases appointed through a nonpartisan screening commission (Chow, 2007). These judges would have relevant background or gain expertise through handling medical negligence cases exclusively (Romano, 2003). Advocates argue that these judges would become more expert in the overlap of the medical and legal arenas and could establish precedents to guide doctors and patients on the proper standard of care. Written rulings setting forth standard of care precedents would promote consistency across fact patterns (Chow, 2007). To maintain the uniformity of judgments, a new medical appellate court would review any appeals (Chow, 2007).

\section{Impartial Experts}

The foremost factor of the tort system's costliness is the pursuit delay of claims in court. Medical negligence claims normally require longer trial time for the fact that most medical negligence cases are determined based on question of fact cantering on complex and technical medical expert evidence. The parties need seeking specialists in particular field and obtaining medical expert records from all sources as well as having conferences with experts and counseling before starting a case. Thus, the delay may occur from while waiting for finding experts and waiting for experts' investigations.

To worsen the situation, it is a sad fact that there is reluctance of doctors to provide evidence that might impose liability on another colleague that is known as "Conspiracy of Silence". In general, the lone satisfactory way of verifying the standard of care is testimony of another doctor. Unfortunately, certain doctors deem that they owe more responsibility to their expert colleagues instead of a public member who undergoes an injury caused by negligence treatment (Kassim, 2008).

Health courts resolve this issue by authorizing judges to select impartial experts in the relevant area of medicine rather than listen to struggling experts hired by the two parties. Still, in certain controversial areas of medicine, impartial experts may not exist, and the current adversarial nature of expert witness testimony may be desirable (Chow, 2007). It is unclear how the health court judges would then decide which expert's opinion to adopt as the standard of care. Despite these uncertainties, by abolishing the use of dueling experts, Common Good claims that health courts would be able to resolve most cases within months and reduce current costs by almost half (Chow, 2007). 
Moreover, health court has ability to answer the problem of conspiracy of salience, which arises from Bolam principle as a standard of care as well as delay occurring because of waiting for finding experts and waiting for experts' investigations by parties. Health court could take doctors' opinions without any reluctance, unwillingness and prejudice.

\section{Health Court Debates}

Health court supporters claim that health courts provide wider accessibility to relief for the people (Tobias, 2005). Inaccessibility of the tort litigation system, particular difficulties of proving medical malpractice, and costly and lengthy period involved in system discourage many potential litigants from pursuing their claim. Through health courts, persons with actual damages to pay for lawyers to make claims, and provide relief for individuals with valid but too small injury claims to warrant complete lawsuit (Mello et al., 2006). Although health courts allow broader access, they also necessitate less compensation for every individual. Therefore, some claim that they prefer institutions and doctors over parties with injury (Farrow, 2010).

In their recently published article, Chen and Sohn (2012) argued that health courts are more cost-effective and efficient. The average time for every jury trial per case is nearly three years and they are costly, comprising costs of attorneys and expert witnesses for both parties. Frequently, administrative costs and attorney fees get most of the money not to the real damaged patient. Even though over $\$ 55$ billion is paid on medical liability litigation annually, less than one percent of that money is in fact given to injured patients. On the other hand, the evidences are given to a panel in health courts that is medically savvy, hiring a liberated professional and reducing the trial time, causing lower attorney fees and less billable hours (Peters, 2008).

Health courts critics indicate research signifying that jury judgments are frequently rather unbiased and studies have revealed a significant relationship between the outcomes of litigation and the merits of misconduct claims when juries are responsible (Tobias, 2005). Similarly, sometimes judges have more specific proficiency in the reform of health care compared to juries and consequently may be better fact finders, resulting in improved and more reliable judgments (Mello et al., 2006).

Supporters also claim that settlements and verdicts are fairer and more rational as health courts depend on specialized judges and fair experts that are more skilled than common judges. Promoters of health courts believe that the existence of such courts that will lead to better patient safety is strongly challenged (Tobias, 2005). Supporters state that transferring the proof burden from neglect to avoidability will motivate doctors to acknowledge faults and let them and their organizations to deal with safety matters more openly and simply (Blake, 2011).

In health courts, a plaintiff should verify that it was possible to avoid injury if the greatest practices had been performed, instead of fulfilling the more challenging standard that negligence of the doctor caused the injury. For example, an unconscious patient taken to the emergency room that is exposed to latex during emergency surgery while he/she is allergic to it can still be compensated as it was not possible to avoid that situation, even though the doctor was not careless. According to Mello et al. (2006), the surgeon could manage to check the chart fast without postponing operation.

Also, health courts promote harmless clinical practices by provision of a better standard of care guidance for physicians. Possibly, the health court as the most thrilling to public health academics function as a central source for claims information that would help to enhance standards of patient safety (Farrow, 2010).

Nevertheless, some claim that the lumping model health court accompanied by acts of negligence and avoidable cases produce less transparency and result in more bold misconduct due to lower fear of financial harm and reduced fear of feeling humiliated amongst medical colleagues (Peters, 2008).

Regardless of some weaknesses which critics of health courts have stated, there are many advantages that we can rely on. Certainly, health court model could answer costly and lengthy period of litigation and difficulties of pursuing claims because of proving the standard of care that involve getting expert opinions in tort.

\section{Conclusion}

By establishing the health court in countries that are in a process of reforming their system for medical negligence cases, the costly and lengthy period of litigation and difficulties of pursuing claims because of proving the standard of care that include achieving expert opinions in tort and difficulties for finding experts to obtain medical experts evidence could be solved. Since the impartial and independence medical assessment will be available at these courts, these courts make more accurate decisions.

Panel of experts or a medically savvy judge is more probable to precisely define whether a plaintiff's injury was just an adverse consequence or the outcome of a medical fault. Health courts can answer delay and costly nature of tort and also the existence of such courts will lead to better patient safety. Finally, safer clinical practices can 
also be encouraged by health courts by provision of better standard of care guidance for physicians. This extended list of probable benefits has created a similarly extended list of advocates including university presidents, medical school deans and a great number of prominent leaders endorse special health courts.

There has been an intensive interest among academic researchers in examining tort difficulties and assessing how well conventional tort reform regulations functioned. Over the past few years, the amount of perfect research has been doubled. But there is still a need to examine other available ways and perform empirical reviews on amount of effect in resolving tort problems after operation and implementation these reforms to create a perfect model for countries that are in a process of reforming their medical negligence compensation system.

\section{References}

Blake, V. (2011). The jury is still out on health courts. Virtual Mentor American Medical Association Journal of Ethics, 13(9), 637-641.

Chen, A. S., \& Sohn, D. H. (2012). Health courts: A potential answer for tort reform. AAOS Now, 6(10). Retrieved from http://www.aaos.org/news/aaosnow/oct12/managing7.asp

Chow, E. (2007). Health courts: An extreme makeover of medical malpractice with potentially fatal complications. Yale Journal of Health Policy, Law, and Ethics, 7(2). Retrieved from http://digitalcommons.law.yale.edu/yjhple/vol7/iss2/4

Danzon, P. M. (1994). Tort reform: The case of medical malpractice. Oxford Review of Economic Policy, 10, 84-98. http://dx.doi.org/10.1093/oxrep/10.1.84

Davies, M. (1998). Medical law. Black Stone Press Limited.

Farrow, F. L. (2010). The anti-patient psychology of health courts: Prescriptions from a Lawyer-Physician. American Journal of Law and Medicine, 36(1), 188-205.

Hitzhusen, M. (2005). Crisis and reform: Is New Zealand's no-fault compensation system a reasonable alternative to the medical crisis in the United States? Arizona Journal of International and Comparative Law, 22(3).

Kassim, P. N. J. (2003). No fault compensation for medical injury: The New Zealand experience. IIUMLJ, 11, 83-95.

Kassim, P. N. J. (2008). Mediating medical negligence claims in Malaysia: An option for reform. MLJ, 4.

Localio, A. R., Lawthers, A. G., \& Brennan, T. A. (1991). Relation between malpractice claims and adverse events due to negligence: Results of the Harvard medical practice study III. N Engl J Med, 325, 245-251. http://dx.doi.org/10.1056/NEJM199107253250405

McLean, S. (1988). No fault liability and medical responsibility. In M. D. A. Freeman (Ed.), Medicine, Ethics and the Law: Current Legal Problems (p.153). London: Steven \& Sons.

Mello, M. M., \& Gallagher, T. H. (2010). Malpractice reform-opportunities for leadership by health care institutions and liability insurers. The New England Journal of Medicine, 362(15), 1353-1356. http://dx.doi.org/10.1056/NEJMp1001603

Mello, M. M., Studdert, D. M., Kachalia, A. B., \& Brennan, T. A. (2006). Health courts and accountability for patient safety. Milbank Q, 84(3), 459-492. http://dx.doi.org/10.1111/j.1468-0009.2006.00455.x

Peters, G. (2008). Health courts? Boston University Law Review, 88, 227-289.

Romano, M. (2003). Trial and error: Medical courts, arbitration systems are among the ideas gaining attention as answers to the malpractice liability crisis. Mod Healthcare, 33, 26-29.

Sohn, D. H., \& Bal, B. S. (2012). Medical malpractice reform: The role of alternative dispute resolution. Clin Orthop Relat Res, 470(5), 1370-1378. http://dx.doi.org/10.1007/s11999-011-2206-2

Studdert, D. M., Mello, M. M., \& Gawande, A. A. (2006). Claims, errors, and compensation payments in medical malpractice litigation. $N$. Engl. J. Med., 354, 2024-2033. http://dx.doi.org/10.1056/NEJMsa054479

Tay, P. S., See, H. P., \& Tan, C. T. (1998). Medical negligence litigation-Call for a reconsideration. MLJ, 3, lxxxi-xcvi.

Tobias, C. W. (2005). Health courts: Panacea or Palliative? University of Richmond L Rev., 40(1), 49-52.

\section{Copyrights}

Copyright for this article is retained by the author(s), with first publication rights granted to the journal.

This is an open-access article distributed under the terms and conditions of the Creative Commons Attribution license (http://creativecommons.org/licenses/by/3.0/). 